\title{
Microbial diversity in the anaerobic tank of a full-scale produced water treatment plant
}

\author{
Ruyin Liu ${ }^{a}$, Dong $\mathrm{Li}^{\mathrm{a}}$, Yingxin Gao ${ }^{\mathrm{a}}$, Yu Zhang ${ }^{\mathrm{a}}$, Song $\mathrm{Wu}^{\mathrm{b}}$, Ran Ding ${ }^{\mathrm{a}}$, \\ Abd El-Latif Hesham ${ }^{\mathrm{a}, \mathrm{c}}$, Min Yang ${ }^{\mathrm{a}, *}$

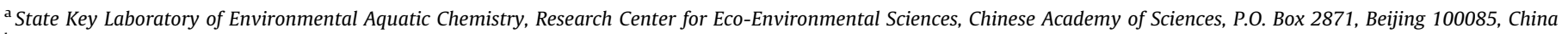 \\ ${ }^{\mathrm{b}}$ Jidong Oilfield, PetroChina, China \\ c Genetics Department, Faculty of Agriculture, Assiut University, Assiut, Egypt
}

\section{A R T I C L E I N F O}

Article history:

Received 15 October 2009

Received in revised form 10 December 2009

Accepted 16 January 2010

Keywords:

Produced water

Anaerobic tank

Biofilm

Archaea

Bacteria

Community

\begin{abstract}
A B S T R A C T
Microbial characteristics in the anaerobic tank of a full-scale produced water treatment plant capable of anaerobic hydrocarbon removal were analyzed and compared to those in the influent produced water using cultivation-independent molecular methods. Clones related to methanogens including the methylotrophic Methanomethylovorans thermophila and hydrogen- and the formate-utilizing Methanolinea tarda were in abundance in both samples, but greater numbers of $M$. tarda-like clones were detected in the biofilm library. Both DGGE and cloning analysis results indicated that the archaea in the biofilm were derived from the influent produced water. Bacterial communities in the influent and biofilm samples were significantly different. Epsilonproteobacteria was the dominant bacterial group in the influent while Nitrospira and Deltaproteobacteria were the predominant groups in the biofilm. Many clones related to syntrophic bacteria were found among the Deltaproteobacteria. One Deltaproteobacteria clone was related to Syntrophus, which is commonly found in methanogenic hydrocarbon-degrading consortia. A number of Deltaproteobacteria clones were assigned to the clone cluster group TA, members of which predominate in various methanogenic consortia that degrade aromatic compounds. These results suggest that a microbial community associated with methanogenic hydrocarbon degradation may have been established in the biofilm.
\end{abstract}

(C) 2010 Elsevier Ltd. All rights reserved.

\section{Introduction}

Produced water, characterized by containing petroleum hydrocarbons, is concurrently recovered during crude oil and natural gas exploration, as well as production in oilfields. Biological processes have been used for the removal of contaminants from produced water [1-3]. In the Jidong Oilfield of China, a full-scale biological system, which consists of successive anaerobic and aerobic biofilm reactors, has been utilized to treat produced water. The anaerobic treatment tank was responsible for the removal of approximately $45 \%$ of the polycyclic aromatic hydrocarbons (PAHs) [4] and $25 \%$ of the total petroleum hydrocarbons (TPH) (this study) from the influent produced water. Although it has been assumed that the biomass in the anaerobic tank plays a key role in the removal of petroleum hydrocarbons, little is known about the microbial populations in the biofilm.

Microbes that utilize petroleum hydrocarbons under aerobic conditions are well known. In the late 1980s, bacteria were isolated

\footnotetext{
* Corresponding author. Tel.: +86 10 62923475; fax: +86 1062923541

E-mail address: yangmin@rcees.ac.cn (M. Yang).
}

and shown to degrade hydrocarbons under anaerobic conditions. Hydrocarbons, including benzene, toluene, ethylbenzene, xylenes, alkanes, and PAHs, could be degraded by coupling them to sulfate reduction, nitrate reduction, or methanogenesis [5-7]. Currently, many anaerobic hydrocarbon-degrading bacteria, which are mainly sulfate-reducing (SRB) and denitrifying bacteria, have been isolated, and the steps in anaerobic metabolism that mediate hydrocarbon degradation have been elucidated in many representative microorganisms. Meanwhile, many library experiments have demonstrated that methanogenic archaea are involved in the anaerobic mineralization of petroleum hydrocarbons. Anderson and Lovley showed that rapid alkane decay via methanogenesis occurred in oilbearing sediments [8], suggesting an important role for methanogenic hydrocarbon degrading organisms in petroleum-rich anaerobic environments. Other investigations have proved the existence of indigenous archaea and bacteria in reservoirs [9], and metabolites indicative of anaerobic hydrocarbon degradation have been isolated from many oil samples [10], suggesting that hydrocarbon-degrading microbial communities are present in oil reservoirs. Thus, whether the microbes from the oil reservoir play a role in the process of anaerobic hydrocarbon degradation in the anaerobic treatment tank in the produced water treatment system is an important question. 
In the present study, the archaeal and bacterial communities in the anaerobic biofilm of the full-scale produced water treatment plant in the Jidong Oilfield were analyzed and compared with those in the influent produced water. Several molecular techniques were used in this analysis, including denaturing gradient gel electrophoresis (DGGE), 16S rRNA gene library construction, and fluorescence in situ hybridization (FISH).

\section{Materials and methods}

\subsection{Sample collection}

The biological treatment system was constructed and put into use in 2001 with a capacity of 5000 tons of wastewater per day. The system consists of two identical series-wound tanks ( $30 \mathrm{~m} \times 18 \mathrm{~m} \times 5.5 \mathrm{~m}$ ) filled with fiber type biocarriers, with the second tank being aerated. The volumetric chemical oxygen demand (COD) load of the system was approximately $0.5 \mathrm{~g} \mathrm{l}^{-1} \mathrm{day}^{-1}$, and the oxidation-reduction potential (ORP) in the water, at a depth of $40 \mathrm{~cm}$ below the surface, was approximately $-130 \mathrm{mV}$ in the first reactor. The biofilm and influent produced water (1 l) samples were taken for DNA extraction in January 2009. The biomass on three biocarriers from the anaerobic tank was shaved and then mixed as the biofilm sample. For the characteristics of water quality, three samples of the influent and the effluents of the anaerobic tank were taken, respectively, over a period of 2 months. All of the samples were collected in sterile bottles and processed in the laboratory within $24 \mathrm{~h}$ after sampling.

\subsection{Water quality analysis}

The conventional water quality parameters of the influent and the effluents of the anaerobic tank were measured according to the standard methods [11]. The characteristics of water samples with standard deviations are listed in Table 1.

\subsection{DNA extraction}

The biofilm and influent samples were washed three times using phosphatebuffered saline (PBS, pH 7.0) and centrifugation at $4{ }^{\circ} \mathrm{C}, 10,000 \mathrm{rpm}$, for $15 \mathrm{~min}$. The genomic DNA was then extracted using the method of Tsai and Olson [12]. Triplet genomic DNA were extracted from the biofilm and influent samples and then pooled.

\subsection{FISH}

Fresh biofilm and influent samples were fixed with $4 \%$ paraformaldehyde in PBS $\left(0.13 \mathrm{M} \mathrm{NaCl}\right.$ in $10 \mathrm{mM} \mathrm{Na}_{2} \mathrm{HPO}_{4}, \mathrm{pH} 7.2$ ), and left for $4 \mathrm{~h}$. The samples were dispersed with sonication and immobilized on glass slides. For hybridizations, probe ARCH 915 labeled with fluorescein isothiocyanate, specific for the domain Archaea was used [13]. Hybridization was performed at $46{ }^{\circ} \mathrm{C}$ for $3 \mathrm{~h}$ with a hybridization buffer $(0.9 \mathrm{M} \mathrm{NaCl}, 20 \mathrm{mM}$ Tris- $\mathrm{HCl}, \mathrm{pH} 7.2,0.01 \% \mathrm{SDS})$ containing labeled probe $\left(5 \mathrm{ng}_{\mu \mathrm{l}^{-1}}\right)$. Hybridization stringency was adjusted by adding formamide to the hybridization buffer (35\% for ARCH915). After hybridization, the slides were washed at $48^{\circ} \mathrm{C}$ for 20 min with washing buffer containing the same components of the hybridization buffer except the probes. To enumerate the total cell number in the samples, the samples were stained with 4',6-diamidino-2phenylindole (DAPI) at a final concentration of $5 \mu \mathrm{g} \mathrm{ml}^{-1}$. Over 1000 DAPI-stained cells were counted to determine the ratio of the probe-labeled cells to the total cells.

\subsection{PCR-DGGE}

In order to minimize PCR bias in PCR-DGGE and subsequent cloning steps, three separate reactions were run for each sample and the results were pooled. The bacterial $16 \mathrm{~S}$ rRNA gene fragments were amplified by PCR using primers $341 \mathrm{~F}\left(5^{\prime}-\right.$ CCT ACG GGA GGC AGC AG-3') with the GC clamp (5'-CGC CCG CCG CGC GCG GCG GGC GGG GCG GGG GCA CGG GGG G-3') attached to the $5^{\prime}$ end and 534R (5'-ATT ACC GCG GCT GCT GG-3') [14]. Touchdown PCR was employed as follows: $95^{\circ} \mathrm{C}$ for $10 \mathrm{~min}$, followed by 20 cycles of $95^{\circ} \mathrm{C}$ for $1 \mathrm{~min}, 65^{\circ} \mathrm{C}$ (reduced by $0.5^{\circ} \mathrm{C}$ each cycle)

Table 1

Quality of the produced water before and after anaerobic treatment.

\begin{tabular}{lll}
\hline Parameter & Value & \\
\cline { 2 - 3 } & Before & After \\
\hline $\mathrm{pH}$ & $7.2 \pm 0.3$ & $7.3 \pm 0.2$ \\
Temperature, ${ }^{\circ} \mathrm{C}$ & $50 \pm 2$ & $50 \pm 2.5$ \\
$\mathrm{COD}, \mathrm{mgl}^{-1}$ & $270 \pm 25$ & $187 \pm 20$ \\
$\mathrm{TPH}, \mathrm{mgl}^{-1}$ & $28 \pm 5$ & $21 \pm 3$ \\
${\mathrm{Total} \mathrm{dissolved} \mathrm{solids,} \mathrm{mgl}^{-1}}_{\mathrm{SO}_{4}{ }^{2-}, \mathrm{mgl}^{-1}}$ & $1400 \pm 30$ & - \\
$\mathrm{NO}_{3}{ }^{-}, \mathrm{mgl}^{-1}$ & $25.5 \pm 2.7$ & $4.7 \pm 1.2$ \\
\hline
\end{tabular}

for $45 \mathrm{~s}$, and $72{ }^{\circ} \mathrm{C}$ for $1 \mathrm{~min}, 10 \mathrm{cycles}$ of $95^{\circ} \mathrm{C}$ for $1 \mathrm{~min}, 55^{\circ} \mathrm{C}$ for $45 \mathrm{~s}$, and $72{ }^{\circ} \mathrm{C}$ for $1 \mathrm{~min}$, and a final extension at $72{ }^{\circ} \mathrm{C}$ for $5 \mathrm{~min}$. Primers ARCH344f ( $5^{\prime}$-ACG GGG YGC AGG CGC GA-3') with the GC clamp and 519r (5'-GWA TTA CCG CGG CKG CTG-3') were used for the domain Archaea [15]. The reaction conditions were as follows: $95{ }^{\circ} \mathrm{C}$ for $5 \mathrm{~min}$, followed by 30 cycles of $95{ }^{\circ} \mathrm{C}$ for $45 \mathrm{~s}, 55^{\circ} \mathrm{C}$ for $45 \mathrm{~s}$, and $72{ }^{\circ} \mathrm{C}$ for $1 \mathrm{~min}$, and a final extension at $72{ }^{\circ} \mathrm{C}$ for $5 \mathrm{~min}$. The resulting amplification products were separated using DGGE with the Dcode Universal Mutation System (Bio-Rad, Hercules, CA, USA). The PCR products $(20-25 \mu \mathrm{l})$ were loaded onto $6 \%(\mathrm{w} / \mathrm{v})$ polyacrylamide gels in Tris-acetate-EDTA buffer ( $\mathrm{pH}$ 7.4). The gels had denaturing gradients of $35-57 \%$ ( $100 \%$ denaturant contains $7 \mathrm{M}$ urea and $40 \%$ formamide) and were run at $150 \mathrm{~V}$ at $60{ }^{\circ} \mathrm{C}$ for $4.5 \mathrm{~h}$. After electrophoresis, the gels were stained for 15 min with ethidium bromide and photographed on a UV transillumination table using a Gel Documentation System (Bio-Rad Laboratories-Segrate, Milan, Italy). DGGE gels were processed using Bio-Rad Quantity One 4.3.0 software.

\subsection{Cloning and sequencing of $16 \mathrm{~S} r \mathrm{DNA}$}

The 16S rRNA gene fragments were amplified by PCR using primers A571F ( $5^{\prime}-$ GCY TAA AGS RIC CGT AGC-3') and UA1406R ( $5^{\prime}$-ACG GGC GGT GWG TRC AA-3') [16] for archaea, 27F (5'-AGA GTT TGA TCC TGG CTC AG-3') and 1492R (5'-GAC GGG CGG TGT GTA C- $3^{\prime}$ ) [17] for bacteria. The conditions for the PCR amplification were: $95{ }^{\circ} \mathrm{C}$ for $10 \mathrm{~min}$, followed by 30 cycles of $95^{\circ} \mathrm{C}$ for $1 \mathrm{~min}, 55^{\circ} \mathrm{C}$ for $1 \mathrm{~min}$, and $72{ }^{\circ} \mathrm{C}$ for $1 \mathrm{~min}$, and a final extension at $72{ }^{\circ} \mathrm{C}$ for $30 \mathrm{~min}$. PCR products were purified using TaKaRa purification kits. The amplified 16S rRNA gene fragments were cloned into the TOPO TA cloning vector PCR2.1, and then TOP10 chemically competent $E$. coli was transformed with the plasmids according to manufacture's instructions (Invitrogen). Transformants were selected by blue-white selection on Luria-Bertani (LB) agar plates containing ampicillin $\left(100 \mu \mathrm{g} \mathrm{ml}^{-1}\right)$. Cloned inserts were amplified from lysed colonies by PCR with plasmid-vector specific primers M13F (5'-GTA AAA CGA CGG CCA G-3') and M13R (5'-CAG GAA ACA GCT ATG AC-3'). Clones were sequenced with an ABI 3730 automated sequencer (Invitrogen, Shanghai, China).

\subsection{Phylogenetic analysis}

Sequences were searched against the Ribosomal Database Project II (RDP II) release 9.49 and the GenBank database by using the BLASTn program to determine the nearest matches. Phylogenetic trees were constructed using MEGA, version 4.0 by the neighbor-joining algorithm, and the Jukes-Cantor distance estimation method with bootstrap analyses for 1000 replicates was performed. The presence of chimerae in the obtained sequences was determined by using the CHECK_CHIMERA (RDP; http://rdp.cme.msu.edu) prior to phylogenetic analysis. The sequences sharing $98 \%$ or greater similarity were considered to represent the same operational taxonomic unit (OTU) using software DOTUR [18].

\subsection{Nucleotide sequence accession numbers}

The partial 16S rRNA gene sequences that were determined have been deposited in the GenBank, nucleotide sequence databases under accession nos. GQ844316GQ844394, and GQ923896-GQ923904.

\section{Results}

\subsection{Performance of the anaerobic treatment system}

The quality of the oilfield produced water before and after anaerobic biological treatment is shown in Table 1. Approximately $80 \mathrm{mg} \mathrm{l}^{-1} \mathrm{COD}$ (30\%) and $7 \mathrm{mg} \mathrm{l}^{-1} \mathrm{TPH}$ (25\%) were removed. Sulfate reduction occurred in the anaerobic tank, with the removal of more than $20 \mathrm{mg} \mathrm{l}^{-1}$ sulfate from the influent produced water. Nitrate was not detected in the produced water.

\subsection{DGGE profiles}

DNA extracted from the influent and anaerobic biofilm samples gave the expected $180 \mathrm{bp}$ archaeal and $200 \mathrm{bp}$ bacterial PCR fragments. DGGE patterns of the PCR products were examined. As shown in Fig. 1A, the influent samples showed more abundant archaeal DGGE bands than the anaerobic tank samples (Coefficient of Dice, 64.4\%). However, all of the archaeal bands in the biofilm samples had corresponding bands in the influent samples, showing that the archaeal representatives in the biofilm originated from the influent produced water. DGGE profiles of the bacterial PCR products, as shown in Fig. 1B, exhibited a lower similarity between the influent and biofilm samples (55.3\%, Coefficient of Dice). 

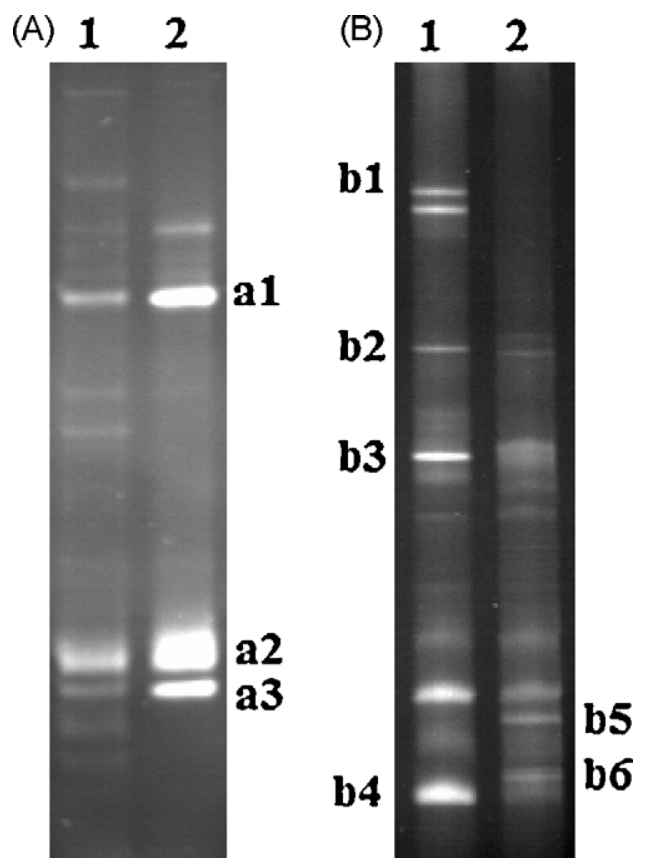

Fig. 1. Denaturing gradient gel electrophoresis profiles for partial $16 \mathrm{~S}$ rDNA fragments showing archaeal (A) and bacterial (B) diversities in the influent (lane 1) and biofilm (lane 2) samples.

Additionally, some bacterial biofilm bands did not have a corresponding band in the influent samples.

Some DGGE bands that were clearly separated from neighboring bands were isolated for sequencing (Table 2). Three archaeal sequences that were obtained were classified in the order Methanosarcinales. All bacterial sequences isolated from the influent were related to uncultured Epsilonproteobacteria clones, and those retrieved from the biofilm (b5 and b6) were affiliated with uncultured clones in the class Betaproteobacteria and Thermotogae, respectively.

\subsection{Diversity and phylogenetic analysis}

To obtain more detailed microbial community information, partial 16S rDNA fragments were PCR-amplified from the extracted DNA using bacterial and archaeal specific primer sets, and four clone libraries were constructed (AP, archaea in the influent produced water; $\mathrm{AB}$, archaea in the biofilm; $\mathrm{BP}$, bacteria in the influent produced water; $B B$, bacteria in the biofilm). Sequences with $\geq 98 \%$ similarity were combined into one operational taxonomic unit (OTU) using the DOTUR software. Thus, 26 and 42 OTUs were obtained from 50 influent and 70 biofilm bacterial clones, respectively, and 6 and 5 OTUs were obtained from 48 influent and 44 biofilm archaeal clones, respectively.
Fluorescence in situ hybridization was also performed to quantify Archaea in both influent and biofilm samples using Archaea (ARCH915)-specific probes [19]. The Archaea cells in the biofilm and influent accounted for approximately $7 \%$ and $10 \%$, respectively, of the total cells (determined by DNA staining with DAPI).

\subsubsection{Analysis of the archaeal communities}

Archaeal clones retrieved from the biofilm and influent samples showed low phylogenetic diversity (Fig. 2). The low archaeal diversity based on analysis of the 16S rRNA gene has also been observed in other high-temperature or hydrocarbon-rich environments, such as hot springs [20] and hydrocarbon-contaminated aquifers [21]. Methanogens were predominant in the archaeal clones, and the methanogen-like clones were distributed among the orders Methanosarcinales and Methanomicrobiales (Table 3). Clones closely related ( $\geq 98 \%)$ to Methanomethylovorans thermophila, an obligate methylotroph, were predominant in the two archaeal clone libraries, but the percentage was higher in the influent (69\% of AP clones, represented by OTU AP13) than in the biofilm ( $57 \%$ of $A B$ clones, represented by OTU AB7). In contrast, the percentage of Methanolinea tarda-like clones was higher in the biofilm library ( $34 \%$ of $A B$ clones, represented by OTU AB1) than in the influent library (10\% of AP clones, represented by OTU AP3 and AP14). M. tarda utilizes $\mathrm{H}_{2}$ and formate for growth and methane production. The remaining non-methanogen clones were affiliated with uncultured archaea clones. Among these, two influent OTUs (AP29 and AP30) were related to clone SCA76 which was retrieved from oil-contaminated soil in the Jidong Oilfield [22].

\subsubsection{Analysis of the bacterial communities}

Phylogenic analysis showed that the majority of 16S rDNA clones in the BB library were distributed among two groups, Nitrospira (40\% of BB clones) and Deltaproteobacteria (20\% of BB clones), while Epsilonproteobacteria clones (74\% of BP clones) predominated in the BP library (Table 4). Moreover, the BB clones were distributed among more diverse phylogenetic groups than the BP clones, suggesting that the bacterial diversity of the biofilm was higher than that of the influent. Taxa that were common to both libraries included Betaproteobacteria, Sphingobacteria, Nitrospira, and Clostridia. Taxa unique to the BB library included eight classes: Deltaproteobacteria, Planctomycetacia, Chloroflexi, Spirochaetes, Actinobacteria, Fusobacteria, Thermotogae, and Verrucomicrobiae. In contrast, Gammaproteobacteria, Epsilonproteobacteria, and Deferribacteres were only detected in the BP library.

In the influent community, the predominant bacterial clones were assigned to the order Campylobacterales in the Epsilonproteobacteria. Seven OTUs representing $48 \%$ of the BP clones were related to Sulfuricurvum sp. (EU498374) in the family Helicobacteraceae, and affiliated with $S$. kujiense, a facultatively anaerobic, chemolithoautotrophic, sulfur-oxidizing bacterium, isolated from an underground crude oil storage cavity. The remaining Epsilonproteobacteria clones were assigned to the family Campylobacteraceae, and most of those were related to clones retrieved from petroleum reservoirs.

Table 2

Nucleotide sequence similarity of sequenced DGGE bands.

\begin{tabular}{|c|c|c|c|c|}
\hline DGGE band & Closest sequence match & Accession No. & Similarity \% & Classification \\
\hline a1 & Uncultured archaeon clone WL-22 from reservoirs & FJ900708 & 98 & Methanosarcinales \\
\hline a2 & Uncultured archaeon clone from anoxic soils & AJ556328 & 100 & Methanosarcinales \\
\hline a3 & Uncultured archaeon clone from anoxic soils & AJ556328 & 100 & Methanosarcinales \\
\hline b1 & Uncultured Campylobacteraceae bacterium & EU640992 & 98 & Epsilonproteobacteria \\
\hline b2 & Uncultured bacterium clone DXH4-98 & FJ558985 & 100 & Epsilonproteobacteria \\
\hline b3 & Uncultured epsilon proteobacterium & AB478659 & 100 & Epsilonproteobacteria \\
\hline b4 & Uncultured bacterium clone 724B10S32 & EU560376 & 99 & Epsilonproteobacteria \\
\hline b5 & Uncultured Hydrogenobacter sp. & FM957578 & 94 & Betaproteobacteria \\
\hline b6 & Uncultured Thermotogales bacterium & AY862075 & 94 & Thermotogae \\
\hline
\end{tabular}






\section{Methanosarcinales}

Methanomicrobiales

Fig. 2. Phylogenetic analysis of archaeal OTUs retrieved from the influent and biofilm samples. Evolutionary dendrog 0.02 indicated changes per nucleotide ( $\mathrm{AP}$, archaeal clone from the influent; $\mathrm{AB}$, archaeal clone from the biofilm).

Nitrospira was the most predominant group in the biofilm community, accounting for $40 \%$ of the BB clones, represented by nine OTUs. Among these, four OTUs representing $18 \%$ of the biofilm clones were affiliated with Thermodesulfovibrio which are known to use $\mathrm{H}_{2}$ with sulfate as the electron acceptor. The other five OTUs clustered together, and were affiliated with uncultured bacteria derived from anaerobic sludge or oil-contaminated sediments.

Most Deltaproteobacteria clones were affiliated with syntrophic substrate-degrading bacteria. Six OTUs representing $12 \%$ of the BB clones were affiliated with a non-sulfate-reducing sub-cluster, group TA (Fig. 3). BB-B38 was affiliated with an uncultured Syntrophorhabdaceae bacterium (clone SJA-51) from a trichlorobenzene-transforming microbial consortium; BB-B40 with an uncultured bacterium (clone WCHB1-27) from a hydrocarbon- contaminated aquifer; BB-HB117 with a clone from a geothermal spring mat with a low similarity of $92 \%$; BB-B2, BB-B20, and BBB93 with Syntrophorhabdus aromaticivorans which can utilize phenol, $p$-cresol, isophthalate, benzoate, and 4-hydroxybenzoate in obligatory syntrophic associations with methanogenic archaea. For OTU BB-LB39, the highest similarity was with the Syntrophus sp. clone B2 identified in a hydrocarbon-degrading methanogenic consortium. Other Deltaproteobacteria OTUs of interest were BBHB110 which was related to the propionate-oxidizing Syntrophobacter sulfatireducens and S. fumaroxidans, and BB-B33 which was affiliated with an uncultured Syntrophaceae bacterium (clone D15_21) retrieved from tar-oil-contaminated aquifer sediments. BB-HB102 was closely related to a clone from a sulfate-reducing reactor and to clone W31 from a water injection well in the Dagang Oilfield, China.

Table 3

Distribution of archaeal OTU and related clone number in phylogenetic groups.

\begin{tabular}{|c|c|c|c|c|c|c|}
\hline \multirow[t]{2}{*}{ Group } & \multicolumn{3}{|l|}{ AB library } & \multicolumn{3}{|l|}{ AP library } \\
\hline & No. of $A B$ clones & No. of OTUs & $\begin{array}{l}\text { Percentage } \\
\text { of total archaeal } \\
\text { clones }\end{array}$ & No. of AP clones & No. of OTUs & $\begin{array}{l}\text { Percentage } \\
\text { of total archaeal } \\
\text { clones }\end{array}$ \\
\hline Methanosarcinales & 26 & 2 & 59 & 34 & 2 & 71 \\
\hline Methanomicrobiales & 16 & 2 & 36 & 5 & 2 & 10 \\
\hline Unknown euryarchaeote & - & - & - & 9 & 2 & 19 \\
\hline Unknown crenarchaeote & 2 & 1 & 5 & - & - & - \\
\hline
\end{tabular}

Table 4

Distribution of bacterial OTU and related clone number in phylogenetic groups.

\begin{tabular}{|c|c|c|c|c|c|c|}
\hline \multirow[t]{2}{*}{ Group } & \multicolumn{3}{|l|}{ BB library } & \multicolumn{3}{|l|}{ BP library } \\
\hline & No. of BB clones & No. of OTUs & $\begin{array}{l}\text { Percentage } \\
\text { of total bacterial } \\
\text { clones }\end{array}$ & No. of BP clones & No. of OTUs & $\begin{array}{l}\text { Percentage } \\
\text { of total bacterial } \\
\text { clones }\end{array}$ \\
\hline Epsilonproteobacteria & - & - & - & 37 & 13 & 74 \\
\hline Gammaproteobacteria & - & - & - & 1 & 1 & 2 \\
\hline Deferribacteres & - & - & - & 2 & 2 & 4 \\
\hline Betaproteobacteria & 4 & 2 & 6 & 5 & 5 & 10 \\
\hline Nitrospira & 28 & 9 & 40 & 2 & 2 & 4 \\
\hline Clostridia & 4 & 4 & 6 & 1 & 1 & 2 \\
\hline Sphingobacteria & 1 & 1 & 1 & 2 & 2 & 4 \\
\hline Deltaproteobacteria & 14 & 11 & 20 & - & - & - \\
\hline Spirochaetes & 3 & 3 & 4 & - & - & - \\
\hline Planctomycetacia & 6 & 2 & 9 & - & - & - \\
\hline Verrucomicrobiae & 2 & 2 & 3 & - & - & - \\
\hline Chloroflexi & 4 & 4 & 6 & - & - & - \\
\hline Actinobacteria & 1 & 1 & 1 & - & - & - \\
\hline Thermotogae & 2 & 2 & 3 & - & - & - \\
\hline Fusobacteria & 1 & 1 & 1 & - & - & - \\
\hline
\end{tabular}


(A)

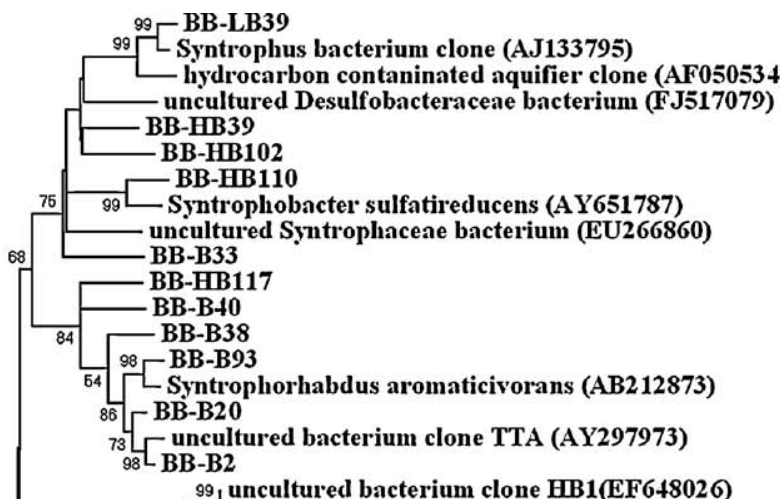

99 uncultured bacterium clone $\mathrm{HB1}(\mathrm{EF} 648026)$

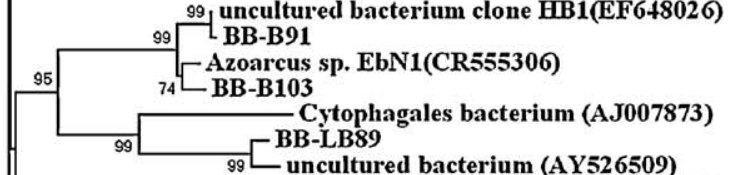

- uncultured bacterium (AY526509)

99
65 uncultured actinobacterium (FM2 42280) 99 uncultured Rubrobacteraceae bacterium (EU266871)

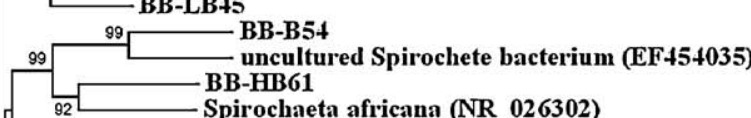

92 Spirochaeta africana (NR_026302)

-BB-B72

uncultured Spirochaetes bacterium (EU721805)



$\stackrel{\longmapsto}{0.02}$

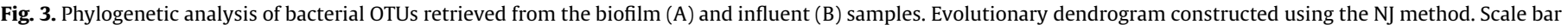
denotes 0.02 indicated changes per nucleotide (BB, bacterial clone from the biofilm; BP, bacterial clone from the influent).

Two biofilm OTUs were assigned to the Betaproteobacteria, and affiliated with Azoarcus spp. Members of the genus Azoarcus can degrade toluene and ethylbenzene, or even alkanes, coupled with nitrate reduction under anoxic conditions [5,23,24]. However, nitrate was not detected in the produced water.

Within the class Clostridia, two OTUs were assigned to the genus Desulfotomaculum. One (BB-HB131) was related to clone Nap2-2B
Deltaproteobacteria

Betaproteobacteria

Sphingobacteria

Fusobacteria

Actinobacteria

Spirochaetes

Clostridia

Nitrospira

Verrucomicrobiae

Planctomycetacia

Chloroflexi

Thermotogae from a hydrocarbon-degrading methanogenic consortium, another (BB-LB52) was related to a bacterium isolated from North Sea oilfield, D. thermocisternum, which can degrade propionate in syntrophic association with methanogenic archaea [25]. In addition, OTU BB-HB48 was related to clone D10_24 from taroil-contaminated aquifer sediments, and OTU BB-B46 was similar to a thermophilic biofilm clone. 


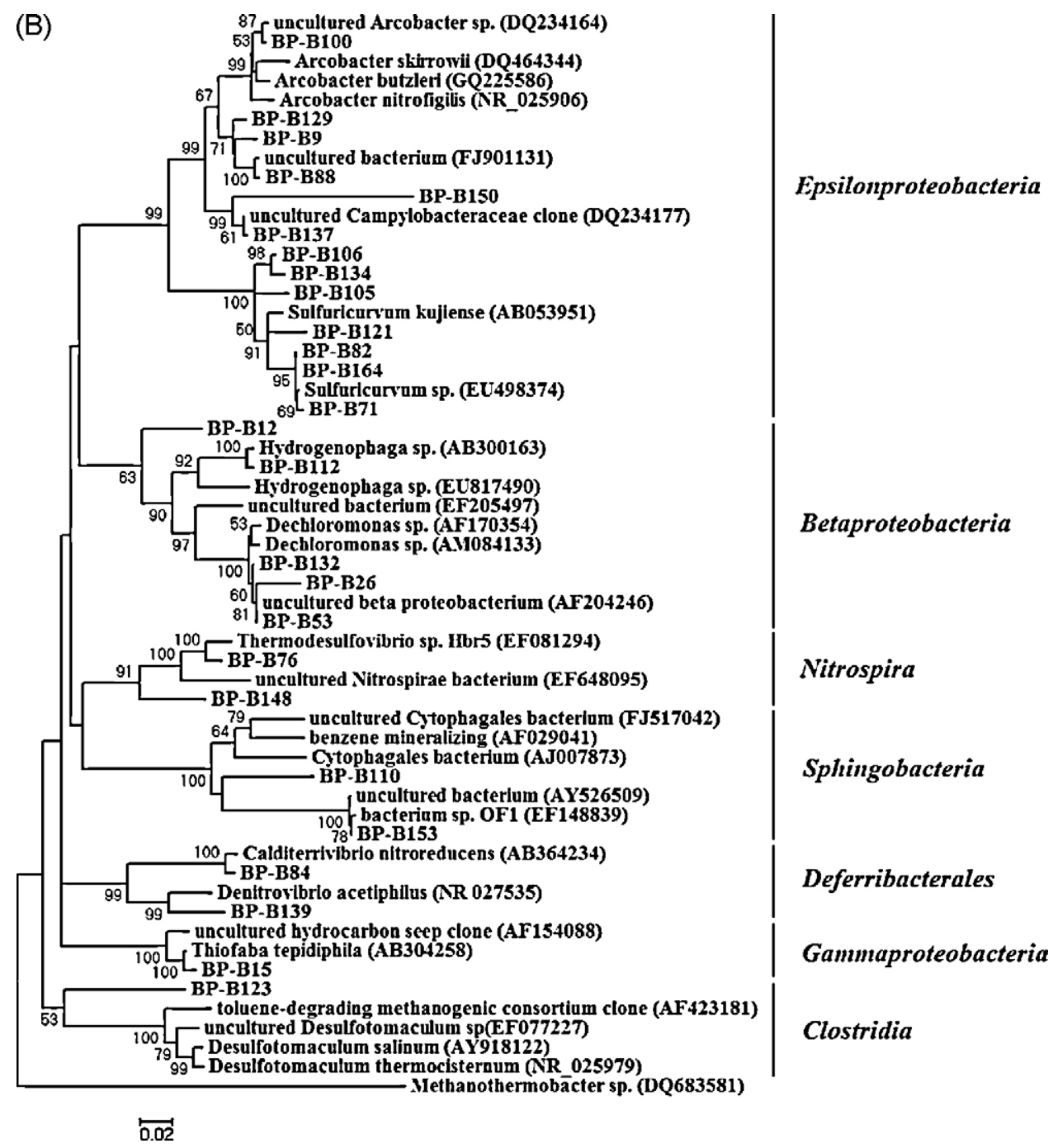

Fig. 3. (Continued).

\section{Discussion}

For archaeal communities, all biofilm DGGE bands had corresponding bands in the influent DGGE profile, and three of the clearly archaeal bands from the biofilm belonged to the order Methanosarcinales. Clones closely related $(\geq 98 \%)$ to the obligate methylotrophic $M$. thermophila in the order Methanosarcinales were predominant in both the biofilm and influent archaeal clone libraries, followed by M. tarda-like clones in the order Methanomicrobiales. Both the DGGE analysis and cloning analysis indicate that archaea in the biofilm were derived from the influent.

$M$. thermophila has been isolated from a thermophilic laboratory-scale upflow anaerobic sludge blanket reactor. M. thermophila can only use methanol and methylated amines as catabolic and methanogenic substrates, with an optimum temperature of $50{ }^{\circ} \mathrm{C}$ [26]. Species of the genus Methanomethylovorans are typical freshwater isolates (having low salt tolerance), whereas the other obligate methylotrophs are generally regarded as halophiles [27]. Many methylotrophic methanogens have been isolated from saline oilfields [9]. This is the first report of the dominant presence of $M$. thermophila in produced water. However, the role of $M$. thermophila-like archaea in the process of pollutant biodegradation will require further study.

The ratio of the hydrogen-utilizing $M$. tarda in archaeal clones increased considerably in the biofilm (from $10 \%$ in the influent to
$34 \%$ in the biofilm). Methanogenic degradation of crude oil hydrocarbons is an important process in oil-contaminated anoxic environments, and methanogenic $\mathrm{CO}_{2}$ reduction is thought to be the predominant methanogenic route [28]. This hypothesis is supported by modeling of the gas isotope composition during inreservoir biodegradation and by data from methanogenic oildegrading microcosms [29], suggesting that hydrogen-utilizing methanogens play an important role in methanogenic hydrocarbon degradation. The hydrogen-utilizing $M$. tarda relatives may play a similar role in the anaerobic reactor.

The bacterial communities in the biofilm and influent were significantly different. Both DGGE and phylogenetic analysis showed that Epsilonproteobacteria was the predominant group in the influent community, whereas no DGGE band or clone from this group was recovered from the biofilm. Epsilonproteobacteria are increasingly recognized in oilfield environments, mainly due to their role in the sulfur cycling in oilfield environments [30,31]. A large number of influent clones (48\%) were affiliated with the chemolithoautotrophic $S$. kujiense, which utilizes nitrate or oxygen as an electron acceptor. The disappearance of Epsilonproteobacteria bacteria in the biofilm is likely to be the result of the strictly anaerobic conditions and lack of nitrate in the anaerobic system (Table 1).

In contrast, Nitrospira was the dominant group in the biofilm clone library (40\%), within which $18 \%$ of bacterial clones were 
related to the sulfate-reducing Thermodesulfovibrio, which use molecular hydrogen as an energy source. This group of bacteria may be related to the removal of sulfate in the anaerobic reactor. Thermodesulfovibrio bacteria are commonly found in thermophilic methanogenic anaerobic sludges [32,33], which are suggested to function in reducing hydrogen partial pressure to ensure that anaerobic substrate degradation is thermodynamically feasible.

Deltaproteobacteria was the second largest bacterial group in the biofilm clone library, while there was no influent clone assigned to the Deltaproteobacteria. Many syntrophic bacteria relatives were found in this class. One Syntrophus-related OTU (BBLB39) was found in the biofilm from the hydrocarbon-degrading anaerobic tank. In a study of methanogenic hexadecane metabolism, sequence analysis revealed that most bacterial clones from the consortium were closely related to the genus Syntrophus [34]. Similarly, Jones et al. found that an oil-degrading consortium derived from river sediment was dominated by Syntrophus sp. [29], suggesting that Syntrophus-related organisms may be responsible for the initial oxidation of hexadecane and oil. Meanwhile, it should be noted that a number of Deltaproteobacteria clones were assigned to a recently recognized clone cluster, the group TA (Fig. 3), which includes bacteria that are predominant in various methanogenic consortia degrading aromatic compounds, such as phenol, terephthalate, and phthalate isomers [35-37]. Thus, bacteria represented by the group TA-related sequences may be associated with anaerobic degradation of PAHs or other aromatic compounds.

In addition, two biofilm OTUs (BB-HB131 and BB-LB52) were affiliated with Desulfotomaculum cluster I in Clostridia. Some cluster I organisms, typically known as gram-positive SRB, have lost the capacity for sulfate respiration and adopt a syntrophic lifestyle in concert with methanogens [38]. Based on their phylogenetic position, these OTUs may play a comparable role in the biofilm. Desulfotomaculum cluster I bacteria have also been observed in an oil-degrading methanogenic consortium [39].

Based on the above phylogenetic analysis, a microbial community associated with methanogenic hydrocarbon degradation may have become established in the biofilm.

\section{Acknowledgements}

This work was supported by the National Natural Science Foundation of China (Contract Nos. 50525824, 50921064) and PetroChina Innovation Foundation (No. 2009D-5006-02-03).

\section{Appendix A. Supplementary data}

Supplementary data associated with this article can be found, in the online version, at doi:10.1016/j.procbio.2010.01.010.

\section{References}

[1] Fakhru'l-Razi A, Pendashteh A, Abdullah LC, Biak DR, Madaeni SS, Abidin ZZ. Review of technologies for oil and gas produced water treatment. J Hazard Mater 2009.

[2] Lu M, Zhang Z, Yu W, Zhu W. Biological treatment of oilfield-produced water: a field pilot study. Int Biodeterior Biodegr 2009;63:316-21.

[3] Zhao X, Wang Y, Ye Z, Borthwick AGL, Ni J. Oil field wastewater treatment in biological aerated filter by immobilized microorganisms. Process Biochem 2006;41:1475-83.

[4] Wang Z, Li J, Hesham Ael L, He S, Zhang Y, Yang M. Co-variations of bacterial composition and catabolic genes related to $\mathrm{PAH}$ degradation in a produced water treatment system consisting of successive anoxic and aerobic units. Sci Total Environ 2007;373:356-62.

[5] Widdel F, Rabus R. Anaerobic biodegradation of saturated and aromatic hydrocarbons. Curr Opin Biotechnol 2001;12:259-76.
[6] Van Hamme JD, Singh A, Ward OP. Recent advances in petroleum microbiology. Microbiol Mol Biol Rev 2003:67:503-49.

[7] Zwolinski, Harris RF, Hickey WJ. Microbial consortia involved in the anaerobic degradation of hydrocarbons. Biodegradation 2000;11:141-58.

[8] Anderson RT, Lovley DR. Hexadecane decay by methanogenesis. Nature 2000;404:722-3.

[9] Magot M, Ollivier B, Patel BK. Microbiology of petroleum reservoirs. Antonie Van Leeuwenhoek 2000;77:103-16.

[10] Aitken CM, Jones DM, Larter SR. Anaerobic hydrocarbon biodegradation in deep subsurface oil reservoirs. Nature 2004;431:291-4.

[11] Andrew DE, Lenore SC, Arnold EG. Standard methods for the examination of water and wastewater. Washington: American Public Health Association; 1998.

[12] Tsai YL, Olson BH. Rapid method for direct extraction of DNA from soil and sediments. Appl Environ Microbiol 1991;57:1070-4.

[13] Amann RI, Zarda B, Stahl DA, Schleifer KH. Identification of individual prokaryotic cells by using enzyme-labeled, rRNA-targeted oligonucleotide probes. Appl Environ Microbiol 1992;58:3007-11.

[14] Muyzer G, de Waal EC, Uitterlinden AG. Profiling of complex microbial populations by denaturing gradient gel electrophoresis analysis of polymerase chain reaction-amplified genes coding for 16S rRNA. Appl Environ Microbiol 1993;59:695-700.

[15] Yu Z Garcia-Gonzalez R, Schanbacher FL, Morrison M. Evaluations of different hypervariable regions of archaeal 16S rRNA genes in profiling of methanogens by Archaea-specific PCR and denaturing gradient gel electrophoresis. Appl Environ Microbiol 2008;74:889-93.

[16] Baker GC, Smith JJ, Cowan DA. Review and re-analysis of domain-specific $16 \mathrm{~S}$ primers. J Microbiol Methods 2003;55:541-55.

[17] Brofft JE, McArthur JV, Shimkets LJ. Recovery of novel bacterial diversity from a forested wetland impacted by reject coal. Environ Microbiol 2002;4:764-9.

[18] Schloss PD, Handelsman J. Introducing DOTUR, a computer program for defining operational taxonomic units and estimating species richness. Appl Environ Microbiol 2005;71:1501-6.

[19] Stahl DA, Flesher B, Mansfield HR, Montgomery L. Use of phylogenetically based hybridization probes for studies of ruminal microbial ecology. App Environ Microbiol 1988;54:1079-84.

[20] Hugenholtz P, Pitulle C, Hershberger KL, Pace NR. Novel division level bacterial diversity in a Yellowstone hot spring. J Bacteriol 1998;180: 366-76.

[21] Dojka MA, Hugenholtz P, Haack SK, Pace NR. Microbial diversity in a hydrocarbon- and chlorinated-solvent-contaminated aquifer undergoing intrinsic bioremediation. Appl Environ Microbiol 1998;64:3869-77.

[22] Ruyin Liu, Yu Zhang, Ran Ding, Dong Li, Yingxin Gao, Yang M. Comparison of archaeal and bacterial community structures in heavily oil-contaminated and pristine soils. J Biosci Bioeng 2009;108:400-7.

[23] Rabus R, Widdel F. Utilization of alkylbenzenes during anaerobic growth of pure cultures of denitrifying bacteria on crude oil. Appl Environ Microbiol 1996;62:1238-41.

[24] Ehrenreich P, Behrends A, Harder J, Widdel F. Anaerobic oxidation of alkanes by newly isolated denitrifying bacteria. Arch Microbiol 2000;173:58-64.

[25] Nilsen RK, Torsvik T, Lien T. Desulfotomaculum thermocisternum sp. nov., a sulfate reducer isolated from a hot North Sea oil reservoir. Int J Syst Bacteriol 1996:46:397-402.

[26] Jiang B, Parshina SN, van Doesburg W, Lomans BP, Stams AJ. Methanomethylovorans thermophila sp. nov., a thermophilic, methylotrophic methanogen from an anaerobic reactor fed with methanol. Int J Syst Evol Microbiol 2005;55:2465-70.

[27] Garcia JL, Patel BK, Ollivier B. Taxonomic, phylogenetic, and ecological diversity of methanogenic Archaea. Anaerobe 2000;6:205-26.

[28] Dolfing J, Larter SR, Head IM. Thermodynamic constraints on methanogenic crude oil biodegradation. ISME J 2008;2:442-52.

[29] Jones DM, Head IM, Gray ND, Adams JJ, Rowan AK, Aitken CM, et al. Crude-oil biodegradation via methanogenesis in subsurface petroleum reservoirs. Nature 2008;451:176-80.

[30] Li H, Yang SZ, Mu BZ, Rong ZF, Zhang J. Molecular analysis of the bacterial community in a continental high-temperature and water-flooded petroleum reservoir. FEMS Microbiol Lett 2006;257:92-8.

[31] Grabowski A, Nercessian O, Fayolle F, Blanchet D, Jeanthon C. Microbial diversity in production waters of a low-temperature biodegraded oil reservoir. FEMS Microbiol Ecol 2005;54:427-43.

[32] Sekiguchi Y, Kamagata Y, Syutsubo K, Ohashi A, Harada H, Nakamura K. Phylogenetic diversity of mesophilic and thermophilic granular sludges determined by 16S rRNA gene analysis. Microbiology 1998;144(Pt. 9): 2655-65.

[33] Roest K, Altinbas M, Paulo PL, Heilig HG, Akkermans AD, Smidt H, et al. Enrichment and detection of microorganisms involved in direct and indirect methanogenesis from methanol in an anaerobic thermophilic bioreactor. Microb Ecol 2005;50:440-6.

[34] Zengler K, Richnow HH, Rossello-Mora R, Michaelis W, Widdel F. Methane formation from long-chain alkanes by anaerobic microorganisms. Nature 1999;401:266-9.

[35] Wu JH, Liu WT, Tseng IC, Cheng SS. Characterization of microbial consortia in a terephthalate-degrading anaerobic granular sludge system. Microbiology 2001;147:373-82. 
[36] Qiu YL, Sekiguchi Y, Imachi H, Kamagata Y, Tseng IC, Cheng SS, et al. Identification and isolation of anaerobic, syntrophic phthalate isomer-degrading microbes from methanogenic sludges treating wastewater from terephthalate manufacturing. Appl Environ Microbiol 2004;70:1617-26.

[37] Zhang T, Ke SZ, Liu Y, Fang HP. Microbial characteristics of a methanogenic phenol-degrading sludge. Water Sci Technol 2005;52:73-8.
[38] Imachi H, Sekiguchi Y, Kamagata Y, Loy A, Qiu YL, Hugenholtz P, et al. Nonsulfate-reducing, syntrophic bacteria affiliated with desulfotomaculum cluster I are widely distributed in methanogenic environments. Appl Environ Microbiol 2006;72:2080-91.

[39] Gieg LM, Duncan KE, Suflita JM. Bioenergy production via microbial conversion of residual oil to natural gas. Appl Environ Microbiol 2008;74:3022-9. 